\title{
Diversity, Uses and Management of Plant Resources in Leasehold Forests of Makwanpur District, Nepal
}

- Ripu M. Kunwar* and Nirmal Adhikar

Leasehold forests for the poor is an approach to address the problems of both poverty and land degradation in Nepal. The lands that were barren at a time of handover in leasehold forestry have now been developed into green lands with trees, grasses and shrubs. However, the more care should be turned to maintain the biodiversity of leasehold forest.

\section{INTRODUCTION}

Over $75 \%$ of energy resources and $40 \%$ of fodder needs are met by forests (HMG/ADB/ FINIDA, 1988). The majority of people use forest products as food, fodder, fibers, fuelwood, fertilizer (5Fs), shelter, cooking, heating, livestock feed and for compost manure. As a result of population growth, over exploitation, habitat destruction and increasing commercial demands for raw materials, pressure upon the existing forest and pasture is ever increasing. It has been recognized that the depletion of the forest resources is the major constraint in poverty alleviation and sustainable development, particularly in hill areas of Nepal. Thus, His Majesty's Government of Nepal (HMGN) has initiated leasehold forestry program for combating rural poverty and arresting forest declination (Yadav and Dhakal, 2000).

Leasehold forestry for poor, by providing the poor with land resource for production, may help to overcome their problems. It provides a unique opportunity for increasing the resources base of the poorest households in the community who are most dependent on forest and grassland resources for their supplies of fodder and fuelwood. The fodder base, which is so vital for the survival of their cattle and hence their own survival has increased by rehabilitating the degraded forestland, enabling them to sustain more productive livestock whilst contributing to environmental protection and conservation at the same time. Regenerated plant species may also provide sustenance needs of human beings. The present work, in this connection, was designed to document the availability, present status and potentiality of plant resources and reveal the conservation measures for sustainable management of plant resources.

\section{Methods}

Present study followed both the PRA and appropriate conventional techniques to obtain required data from primary and secondary sources. Field visits were carried out in February and March 2002. Field observations, discussions and semi-structured interviews with the lessee were undertaken as the form of participatory approach. Field observations were done by transact walks inside the selected forests. Efforts were made to cover the whole area of the forest in the foot trial. Semi structured and informal interviews were held with lessee groups. District Forest Officer, rangers and stakeholders were also consulted. In order to get relevant information, the key informants including farmer leaders, professionals, teachers, range-post in-charges were cross checked. Secondary information was collected by reviewing the past and on going works of leasehold forestry programs. A dual approach was used in analyzing the data, implying the use of both quantitative and qualitative methods of analysis.

Sample leasehold forests and their user groups (lessee) were Campadanda leasehold forest user group of Basamadi village development committee and Ramanthali, Aadmara and Gaidadhap leasehold forest user groups of Padampokhari village development committee from Makwanpur district. Both the VDCs are situated close to Hetauda municipality just at $10 \mathrm{Km}$ distance. The climate of study area is pure tropical ranging from $400-500$ masl.

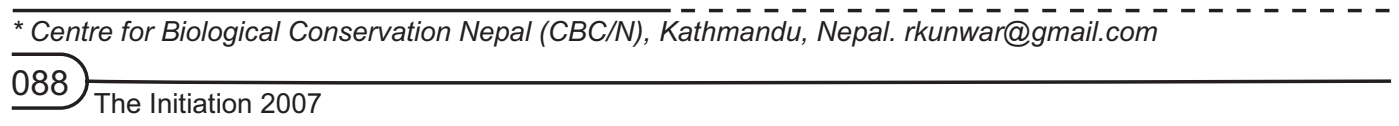




\section{Results and Discussion}

\section{Plant diversity}

Leasing of denuded land under leasehold forest contributed not only to increase the greenery but also to enhance the biodiversity. Altogether 78 plant species belonging to 28 families were recorded. Diversity of Leguminosae was found the most. Most of the studied forests were dominated by Sal (Shorea robusta) and its associated species Terminalia bellirica, T. tomentosa, Semecarpus anacardium, Dalbergia sisoo, Eucalyptus cameldulensis, Leucaena leucocephala etc. The species were naturally sprouted from remnant trees and planted by lessee groups. Regeneration and plantation of different species has made the leasehold forests diverse and dense (Table 1). Upper stratum was dominated by Shorea robusta. The ground coverage was dominated by Stylo, Molasses, Imperata cylindrica, and seedlings of Shorea robusta. The result was due to purposefully relegation of shrubs' and other tree species' seedlings and management of Sal seedlings and grass species, which fetch high economic returns to lessee.

Table 1. Dominant plant vegetation of leasehold forests

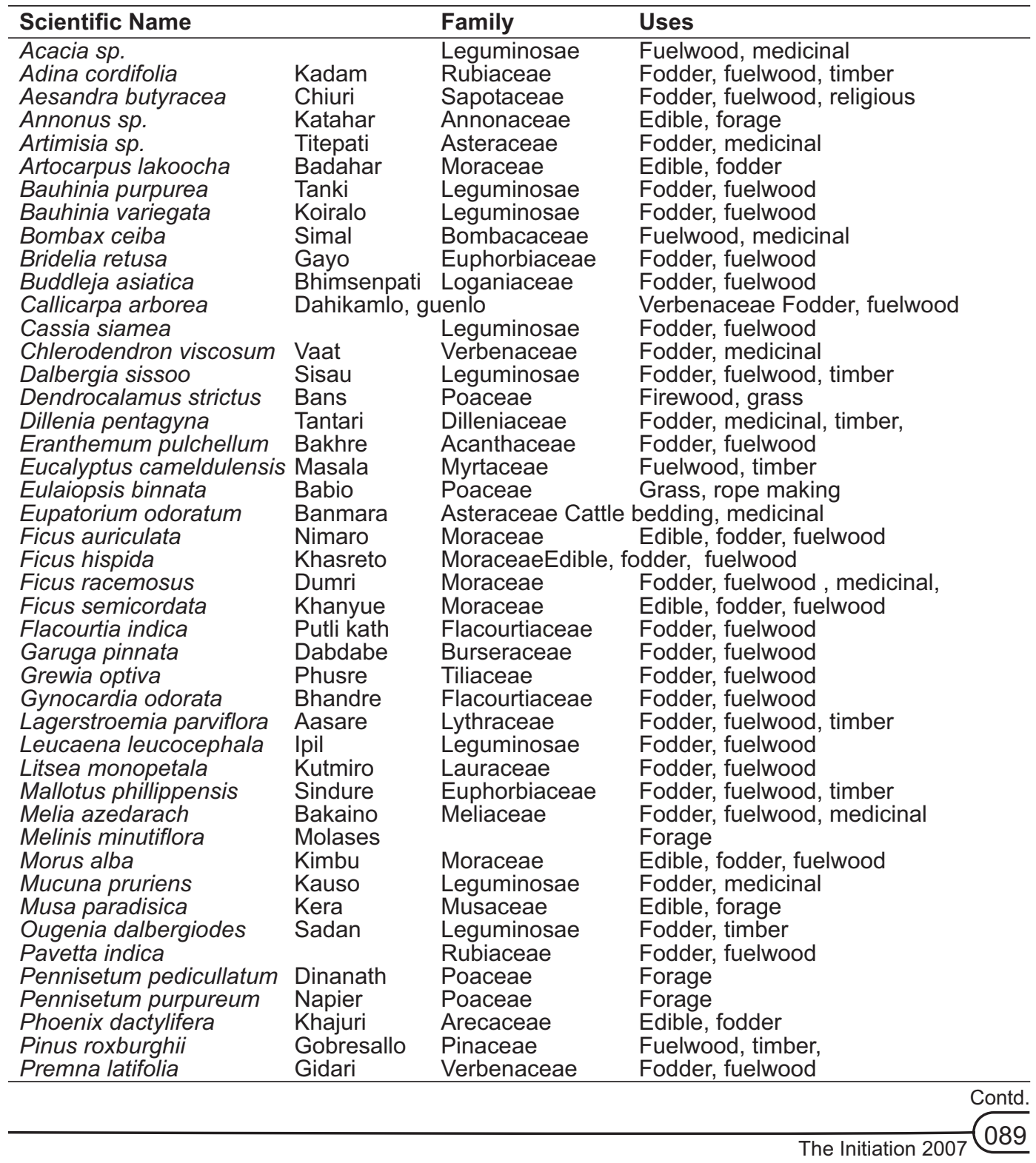




\begin{tabular}{llll}
\hline Scientific Name & & Family & Uses \\
\hline Psidium guajava & Aamba & Myrtaceae & Edible, fuelwood \\
Schima wallichii & Chilaune & Theaceae & Fuelwood, timber, \\
Semecarpus anacardium & Bhalayo & Anacardiaceae & Medicinal, timber, \\
Shorea robusta & Sal & Dipterocarpaceae & Fodder, timber \\
Sterculia villosa & Odaal & Sterculiaceae & Fodder, fuelwood, \\
Stylosanthes guianensis & Stylo & Leguminosae & Forage \\
Syzygium operculatus & Kyamuno & Myrtaceae & Edible, fuelwood, timber \\
Terminalia alata & Saaj & Combretaceae & Fodder, medicinal, timber \\
Terminalia chebula & Barro & Combretaceae & Fodder, medicinal, timber \\
Thysanolaena maxima & Amriso & Poaceae & Broom making, fodder \\
\hline
\end{tabular}

In Makawanpur district, total 247 leasehold forest user groups have been formed which have managed 1026.32 ha of degraded land. Plantation and management of fodder and forage plant species in leasehold forests was the most exercised. Development of fodder and forage species have increased their livestock rearing capacity which consequently increase agriculture product and household economy. Especially grasses/forage species such as Napier, Stylo, etc. contributed substantial to the locale by providing good forage and high priced seed (Rs. 400/kg).

As livestock rearing is the main occupation, fodder plants are the main sustenance of the people. Lessee groups have provided better care for development and management of fodder plant species. Fodder plants not only provide the food for livestock but also increase the agricultural productivity and provide rural fuelwood energy from the fodder and forage residue. Altogether 47 fodder/forage/grass species were recorded. Leguminosae and Moraceae were the dominant families contributing the highest number of fodder plant species; nine and six species each (Table 1).

\section{Medicinal plants}

Richness of medicinal plants was quite good (Table 2). Altogether, 40 medicinal plant species were reported which were naturally regenerated. Very few were planted after lease. Abundance of medicinal plants in Ramanthali leasehold forest was higher comprising $85 \%$ of the total recorded species. Total 10 species of medicinal plants were distributed in all leasehold forests. The commonly distributed medicinal plant species were Acacia catechu, Cassia fistula, Centella asiatica, Litsea monopetala, Mangifera indica, Shorea robusta, Syzygium cuminii, Terminalia alata, T. bellirica and T. chebula.

Table 2: Some important medicinal plants along with their distribution

\begin{tabular}{|c|c|c|c|c|}
\hline Scientific name & $\begin{array}{l}\text { Campadanda } \\
\text { leasehold forest }\end{array}$ & $\begin{array}{l}\text { Ramanthali } \\
\text { leasehold forest }\end{array}$ & $\begin{array}{l}\text { Aadmara } \\
\text { leasehold forest }\end{array}$ & $\begin{array}{l}\text { Gaidadhap } \\
\text { leasehold forest }\end{array}$ \\
\hline Acacia catechu & + & + & + & + \\
\hline Adhatoda vasica & & + & + & + \\
\hline Adina cordifolia & + & & & \\
\hline Aegle marmelos & + & + & & + \\
\hline Agave $s p$. & & + & + & + \\
\hline Alstonia scholaris & + & & & \\
\hline Asparagus racemosus & + & + & & \\
\hline Aesandra butyracea & + & + & & + \\
\hline Cassia fistula & + & + & + & + \\
\hline Centella asiatica & + & + & + & + \\
\hline Cinnamommum camphora* & & + & & \\
\hline Cinnamommum glaucescense & & + & + & + \\
\hline Cymbopogon citratus* & & + & + & + \\
\hline Euphorbia royalena & + & + & & + \\
\hline Flemingia microflora & & + & + & + \\
\hline Indigofera sp. & + & + & & + \\
\hline Litchi chinensis* & & + & & \\
\hline Mangifera indica* & + & + & + & + \\
\hline Murrya koenigii & + & & & \\
\hline Phyllathus emblica & & + & + & + \\
\hline Rauvolfia serpentina & & + & + & \\
\hline Santalum album* & & + & & \\
\hline
\end{tabular}




\begin{tabular}{|c|c|c|c|c|}
\hline Scientific name & $\begin{array}{l}\text { Campadanda } \\
\text { leasehold forest }\end{array}$ & $\begin{array}{l}\text { Ramanthali } \\
\text { leasehold forest }\end{array}$ & $\begin{array}{l}\text { Aadmara } \\
\text { leasehold forest }\end{array}$ & $\begin{array}{l}\text { Gaidadhap } \\
\text { leasehold forest }\end{array}$ \\
\hline Shorea robusta & + & + & + & + \\
\hline Syzygium cumini & + & + & + & + \\
\hline Terminalia bellirica & + & + & + & + \\
\hline Terminalia chebula & + & + & + & + \\
\hline Terminalia alata & + & + & + & + \\
\hline Woodfordia fructicosa & + & & & \\
\hline Total & 18 & 24 & 16 & 19 \\
\hline
\end{tabular}

+ Presence, * Planted species

\section{Potential species}

As per objectives, lessee groups are being provided the seedlings, seeds and knowledge of about forage and fodder species. The development of fodder and forage species have contributed the lessee to increase their livestock rearing capacity, which consequently increases the agricultural product, provides the rural energy and has increased the household economy. In present days, emphasis has been confined on fodder species although there are many other potential aspects, which would be better if included in policy as well as in implementation level.

The commercial scale of plantation and domestication of medicinal and aromatic plants and other economically important species in lease land will not only increase the biodiversity but also diversify the livelihood strategies and income generating activities of lessee groups. Medicinal and aromatic plants, multipurpose plant species and nitrogen fixing species are considered as the best biological resources, which have very high potentiality in the economy and ecology. Plant species such as Asparagus racemossus, Rauvolfia serpentina, Cassia fistula, Aegle marmelos, Cymbopogon sp, etc. were observed as potential medicinal plants of leasehold forests of Makawanpur district. Therefore, the provision for the cultivation and domestication of such plant species should be administered. By giving the emphasis on different plant species, the chance of being monoculture habitat could also be minimized and diversity will be increased.

\section{Policies}

The provision for leasehold forestry is included after Master Plan for Forestry Sector (MPFS 1988) under Forest Act 1961 amended in 1977. Leasing the forestland to the local poor for their economic upliftment was started just after 1999. Since, lessee groups got the official recognition and started to workout many income generating activities. As the program initially aimed to alleviate the poverty and rehabilitate the degraded forestland, emphasis has also been given to enhance the animal husbandry by encouraging the lessee in fodder species plantation (Singh, 2000). Contrarily, provision for the plantation and domestication of important non-timber forest products, medicinal and aromatic plants, nitrogen fixing species, and other multipurpose plant species was not included in the leasehold forestry objectives and work plan. It shows that the research gap and some sorts of policy constraints regarding to cover the potential fields including cultivation, processing, value addition and marketing of such plants and diversifying the livelihood portfolios are pronounced. Policy and legislation, therefore, should turn to address the diversifying of the lessee group's livelihood strategies.

It is evident that almost all lessees were tempted towards the cultivation of single species Stylo to fetch its highly priced seed and forage value. Though it has generated good amount, which facilitates to sustenance of lessee, the practice may ultimately convert the land to monoculture stands of Stylo species. Managing the forest solely for single species cannot fulfill all the needs of the community. Therefore, it is imperative to manage the forest with eco-friendly multi-species for sound ecosystem and capital of long-term income generating activities. 


\section{Conclusion}

Leasehold forestry program is one of the poverty alleviation programs through restoration of degraded land leased to rural poor. In order to increase the biodiversity and lessee's household economy consideration should be given to various plant species including non-timber forest products, medicinal and aromatic, multipurpose and nitrogen fixing plant species. A systematic and regular research should be conducted to maintain the plant people harmony.

\section{References}

HMG/ADB/FINNIDA 1988 Master Plan for forestry Sector in Nepal, MoFSC, Kathmandu Nepal.

Singh, B. K. 1998. Community Forestry in Nepal: Gradual Movement from subsistence to monetise sector of economy Banko Janakari Vol. 8 (1): 46-49. Kathmandu, Nepal

Singh, B. K. 2000. Institutional strengthening in leasehold in leasehold forestry through cooperatives. Banko Janakari, 10(2): 35-39

Yadav, R. P. and A. Dhakal, 2000 Leasehold Forestry for Poor an Innovative pro-poor program in the Hills of Nepal, HMG / WINROCK. Policy Outlook Series No. 6.

\section{What is gender?}

\section{- Nava Raj Baral} IOF Pokhara.

Man is a social animal. A man gets birth and dies in the society. The environment plays the vital role to shape the being. A person, sex does not affect his /her being.It is rather the society that gives the importance. In some society males are given a priority where as in some other societies those females are given the priority. The cultural norms and value, the society and other different aspect of the society, creates the norms and values that determine the identity of male and female.

Man is a biological animal. The chromosome and hormone determine the sex. It is the sex organ that determine male and female.

Man bears different attributes. When he/she gets birth he only receives the body. Social norms and values are taught by society and its inhabitants. Hence a person gets the identity of man and woman. This process of sex determine by gendering.

The word gender was used by Anne Cakloy in 1970, in order to clarify the concept of human development. In 1980, this was adapted as development approach. The human development in 1980, this was adapted as a development approach. The human development report 1995 published by UNDP warned the whole world saying 'Development it not endangered will be endangered.'

The male has penis and female has vagina. It is only the concept that makes superior and inferior. Gender only explains the relationship and differentiate male and female inferior.

Hence, the word Gender itself is broad term. It is not to be understood in narrow way. Gender biasness should be eliminated from the society. Every woman should be empowered to participate in the main stream of the social activities. 